\title{
7. DISTRIBUTION OF GOLD, PALLADIUM, PLATINUM, RHODIUM, RUTHENIUM, AND IRIDIUM IN LEG 115 HOTSPOT BASALTS: IMPLICATIONS FOR MAGMATIC PROCESSES ${ }^{1}$
}

\author{
John D. Greenough ${ }^{2}$ and Brian J. Fryer ${ }^{3}$
}

\begin{abstract}
A comparison of 50 basalts recovered at Sites 706, 707, 713, and 715 along the Réunion hotspot trace during Ocean Drilling Program Leg 115 in the Indian Ocean shows that seafloor alteration had little effect on noble metal concentrations (Au, Pd, Pt, Rh, Ru, and Ir), determined by inductively coupled plasma-mass spectrometry (ICP-MS), which generally tend to decrease with magma evolution. Their compatible-element behavior may be related to the precipitation of Ir-Os-based alloys, chromite, sulfides, and/or olivine and clinopyroxene in some combination. The simplest explanation indicates silicate control of concentrations during differentiation.

Basalts from the different sites show varying degrees of alkalinity. Noble metal abundances tend to increase with decreasing basalt alkalinity (i.e., with increasing percentages of mantle melting), indicating that the metals behave as compatible elements during mantle melting. The retention of low-melting-point $\mathrm{Au}, \mathrm{Pd}$, and $\mathrm{Rh}$ in mantle sulfides, which mostly dissolve before significant proportions of $\mathrm{Ir}$-Os-based alloys melt, explains increasing $\mathrm{Pd} / \mathrm{Ir}$ ratios with decreasing alkalinity (increasing melting percentages) in oceanic basalts. High noble metal concentrations in Indian Ocean basalts (weighted averages of $\mathrm{Au}, \mathrm{Pd}, \mathrm{Rh}, \mathrm{Pt}, \mathrm{Ru}$, and $\mathrm{Ir}$ in Leg 115 basalts are 3.2, 8.1, 0.31, 7.3, 0.22, and $0.11 \mathrm{ppb}$, respectively), compared with basalts from some other ocean basins, may reflect fundamental primary variations in upper-mantle noble metal abundances.
\end{abstract}

\section{INTRODUCTION}

In recent years a wide variety of processes have been proposed to account for the distribution and concentrations of the noble metals in mafic systems. Some of these include partial melting of the mantle (Campbell and Barnes, 1984; Brugmann et al., 1987); crystal fractionation of silicate phases (Crocket, 1981; Brugmann et al., 1987); oxide phases (Crocket and Chyi, 1972; Agiorgitis and Wolf, 1978); platinum-group-element-bearing (PGE-bearing) alloys (Bird and Basset, 1980; Keays, 1982); segregation of an immiscible sulfide liquid (Hertogen et al., 1980; Hamlyn et al., 1985); and processes related to the movement of volatiles at various stages in the evolutionary cooling history of a magma (Boudreau et al., 1986; Schiffries and Skinner, 1987; Wood, 1987).

The behavior of the noble metals during these processes is only poorly understood, but their net effect often results in element fractionation in order of descending melting point: Os, Ir, $\mathrm{Ru}, \mathrm{Rh}, \mathrm{Pt}, \mathrm{Pd}$, and $\mathrm{Au}$ (Barnes et al., 1985). The varied geochemical behavior of the noble metals indicates that they should provide new insights into mantle evolution, core-mantle differentiation, magma differentiation, and the formation of sulfide ore deposits that cannot easily be gleaned from the more commonly studied lithophile, siderophile, and chalcophile elements.

Investigations of oceanic-island basalts (OIB) have traditionally acted as cornerstones for understanding mantle evolution processes. Because they are present in ocean basins, the interpretation of OIB petrogenesis is simplified by the assumption that they have probably not assimilated continental crust. Oceanic-island magmas show compositional ranges that reflect various amounts of mantle-source enrichment in the large-ion litho-

${ }^{1}$ Duncan, R. A., Backman, J., Peterson, L. C., et al., 1990. Proc. ODP, Sci. Results, 115: College Station, TX (Ocean Drilling Program).

${ }^{2}$ Department of Geology, Mount Allison University, Sackville, New Brunswick, Canada, EOA $3 \mathrm{CO}$.

${ }^{3}$ Department of Earth Sciences, The Memorial University of Newfoundland, St. John's, Newfoundland, Canada A1B 3X5. phile elements (LILE; e.g., $\mathrm{K}$ and $\mathrm{Rb}$ ) and high-field-strength elements (e.g., $\mathrm{Zr}$ and $\mathrm{Nb}$; Sun and Hanson, 1975) relative to mid-ocean-ridge basalts (MORB), and various percentages of partial melting in their source regions (Gast, 1968). Magmas representing the cumulative effects of these and other mantle processes are variably alkaline and, as a result, follow assorted differentiation paths during evolution in lithospheric magma chambers. The OIB, therefore, are ideally suited to studies of noble metal behavior during mantle melting and differentiation processes. Curiously, no comprehensive studies of the noble metals in OIB have as yet been reported.

Basalts for this study were collected at four locations along the Réunion hotspot trace during Leg 115 (Fig. 1). Preliminary shipboard studies indicated that rocks from separate sites show different degrees of alkalinity and that basalts from any one site are variably evolved (Backman, Duncan, et al., 1988; Fisk et al., 1989). In this paper we document the concentrations of $\mathrm{Au}$, $\mathrm{Pd}, \mathrm{Rh}, \mathrm{Pt}, \mathrm{Ru}$, and Ir in $49 \mathrm{Leg} 115$ basalts by means of ICPMS methods of analysis developed at The Memorial University of Newfoundland, Canada. These data were used in conjunction with shipboard major and trace element data to place constraints on the behavior of noble metals during basalt petrogenesis. For thorough discussions of the geochemical and mineralogical attributes of Leg 115 basalts, the reader is referred to petrology studies elsewhere in this volume.

\section{DESCRIPTION OF SAMPLES}

On the basis of petrographic descriptions as well as major and trace element analyses, samples were selected on board the JOIDES Resolution such that the maximum range of rock compositions from each site $(706,707,713$, and 715$)$ were analyzed for their noble metal concentrations. Samples from each site can be placed into two groups according to their degree of evolution (based on $\mathrm{Fe} / \mathrm{Mg}$ ratios). For each site, Group $\mathrm{E}$ basalts are always the most evolved and Group P the most primitive. Site 715 has two evolved groups (an upper, 715-UE, and a lower, 715-LE, on the basis of height in the hole) and two primitive groups (an upper and lower, symbolized as 715-UP and 715-LP, respectively). Samples lumped into one group could come from 


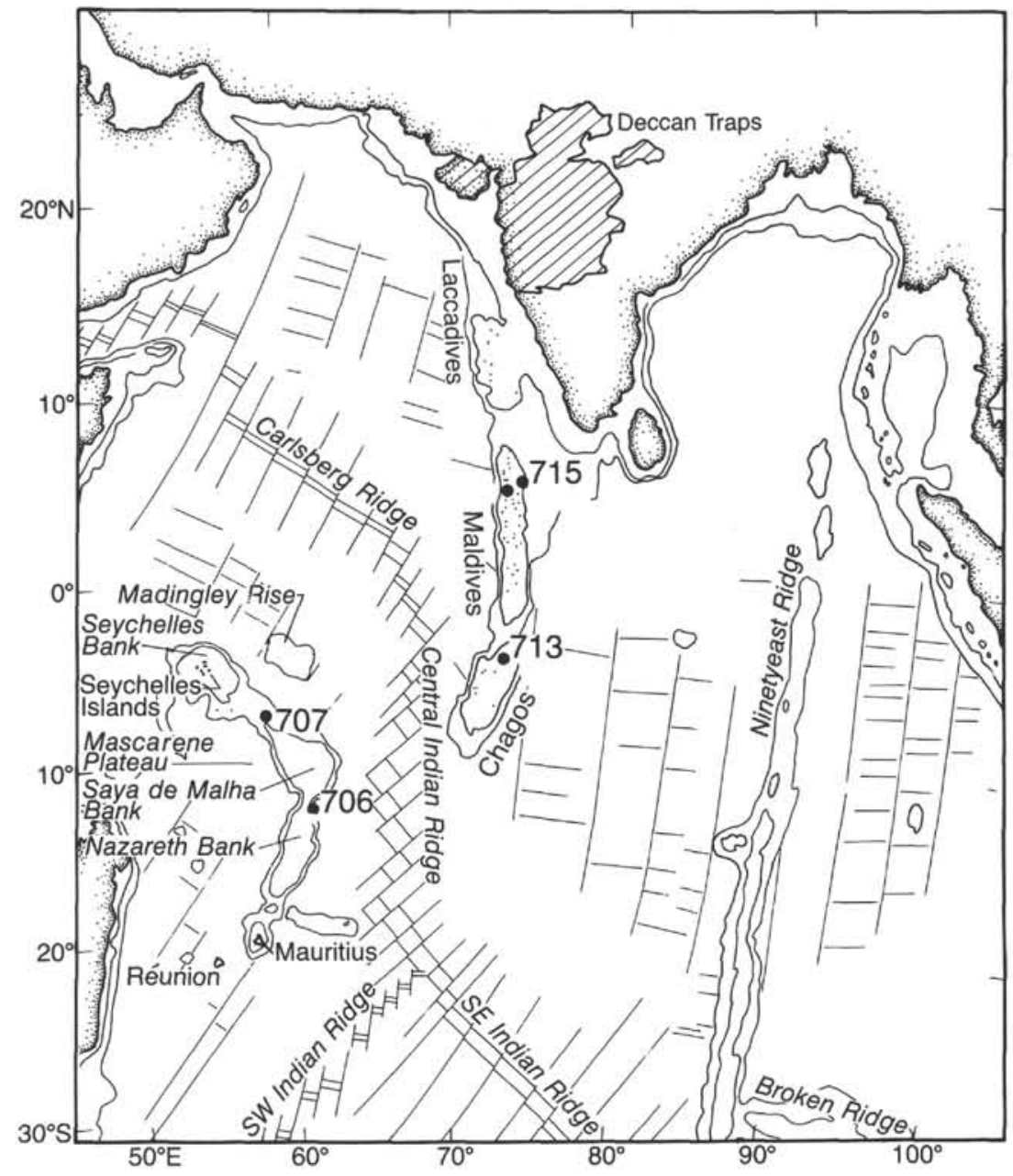

Figure 1. Map showing the location of Leg 115 hard-rock sites and the Réunion hotspot trace. Modified from Duncan et al., 1988.

several distinct lava flows or a single flow. The following background and petrographic information is derived from shipboard data (Backman, Duncan, et al., 1988; Duncan et al., 1989).

Basalts from Site 706 were dated paleontologically as early Oligocene $(\sim 35 \mathrm{Ma})$ and radiometrically at $33 \mathrm{Ma}$ (Duncan and Hargraves, this volume). They erupted when the hotspot coincided with the Central Indian Ridge. Group 706-E samples come from Cores $115-706 \mathrm{C}-2 \mathrm{R}$ through -9R (17 samples analyzed for PGE; the sample locations appear as sample numbers in Table $1)$ and contain zoned plagioclase $(\sim 15 \%, 0.5 \mathrm{~mm})$ and augite $(\sim 10 \%, 0.4 \mathrm{~mm})$ microphenocrysts, the latter purplish in color (which indicates a high $\mathrm{TiO}_{2}$ content) and locally glomeroporphyritic. Olivine phenocrysts $(1 \%-2 \%)$ are totally altered to clay minerals. The vesicular to highly vesicular $(5 \%-20 \%)$ basalts have a fine-grained ( $\leq 0.1 \mathrm{~mm}$ ) to glassy (devitrified) matrix that often shows radiating crystals of clinopyroxene as well as Fe-Ti oxides that indicate quenching. Alteration phases (for the most part, celadonite) compose $10 \%-50 \%$ of each sample, replace glass and matrix minerals, and fill vesicles. Numerous glassy contacts, fine-grained textures, and high vesicularity indicate that these are pillow basalts erupted at fairly shallow water depths.

Group 706-P basalts ( 3 samples, bottom of Core 115-706C9R) contain an abundance $(15 \%)$ of large $(\leq 7 \mathrm{~mm})$ equant plagioclase phenocrysts, but they tend to be poorer in augite phe- nocrysts $(\leq 10 \%,<2 \mathrm{~mm})$ than Group $706-\mathrm{E}$ basalts. They are medium to fine grained and less vesicular $(\leq 10 \%)$ than the overlying basalts, but they do display similar alteration mineralogy.

The early Paleocene basalts (64 Ma, as per Duncan and Hargraves, this volume) from Site 707 (between the Mascarene Plateau and Seychelles Bank; see Fig. 1) can be linked in time and space with continental Deccan trap volcanic activity in western India, although it is now separated from the latter as a result of subsequent seafloor spreading. The basalts fall into two geochemical groups. Group 707-P samples (4 samples) contain augite and plagioclase microphenocrysts (5\%-30\% total) with augite dominant and locally glomeroporphyritic in samples from Core 115-707C-22R and plagioclase dominant in Core 115-707C$23 R$. Olivine phenocrysts $(2 \%$ ?) always appear altered to brown clay minerals. The lower basalts (Core 115-707C-23R) are medium to coarse grained, subophitic, and nonvesicular, whereas the upper ones are fine grained and often display intersertal and highly vesicular $(10 \%-30 \%)$ textures. Alteration averages about $20 \%$ in the samples, with brown clay minerals and minor calcite replacing glass and matrix minerals as well as filling vesicles.

Group 707-E (3 samples) contains microphenocrysts of augite $(7 \%,<0.5 \mathrm{~mm})$, plagioclase $(3 \%,<2 \mathrm{~mm})$, and possibly olivine ( $1 \%$, always altered). Vesicles $(\leq 5 \%)$ are filled with calcite and brown clay minerals. Clay minerals also replace por- 
Table 1. Noble metal abundances (ppb) in Leg 115 basalts.

\begin{tabular}{|c|c|c|c|c|c|c|c|}
\hline Unit & $\begin{array}{l}\text { Core, section, } \\
\text { interval }(\mathrm{cm})\end{array}$ & $\mathrm{Au}$ & $\mathrm{Pd}$ & Rh & Pt & Ru & Ir \\
\hline 706-E & $115-706 \mathrm{~A}-6 \mathrm{H}-\mathrm{CC}, 21-23$ & 0.70 & 1.20 & 0.08 & 0.90 & 0.19 & 0.13 \\
\hline 706-E & $115-706 \mathrm{C}-2 \mathrm{R}-2,74-77$ & 0.55 & 0.99 & 0.08 & 1.30 & 0.08 & 0.12 \\
\hline 706-E & $115-706 \mathrm{C}-2 \mathrm{R}-2,142-146$ & 0.67 & 0.81 & 0.07 & 1.02 & 0.07 & 0.11 \\
\hline 706-E & $115-706 \mathrm{C}-3 \mathrm{R}-1,83-85$ & 0.58 & 1.01 & 0.05 & 0.94 & 0.05 & 0.07 \\
\hline 706-E & $115-706 \mathrm{C}-3 \mathrm{R}-2,45-47$ & 0.49 & 0.75 & 0.09 & 1.04 & 0.10 & 0.12 \\
\hline 706-E & $115-706 \mathrm{C}-4 \mathrm{R}-1,78-80$ & 0.61 & 1.14 & 0.07 & 1.83 & 0 & 0.12 \\
\hline 706-E & $115-706 \mathrm{C}-4 \mathrm{R}-2,116-119$ & 0.68 & 0.94 & 0.08 & 1.12 & & 0.14 \\
\hline 706-E & $115-706 C-5 R-2,52-56$ & 0.70 & 0.71 & 0.04 & 0.59 & 0.06 & 0.09 \\
\hline 706-E & $115-706$ C-5R-2, $135-137$ & 0.86 & 1.86 & 0.12 & 2.47 & & 0.09 \\
\hline 706-E & $115-706 C-5 R-3,59-62$ & 0.47 & 1.03 & 0.11 & 1.09 & 0.06 & 0.12 \\
\hline 706-E & $115-706 \mathrm{C}-6 \mathrm{R}-1,45-50$ & 0.59 & 0.26 & 0.05 & 1.81 & 0.02 & 0.10 \\
\hline 706-E & $115-706 \mathrm{C}-6 \mathrm{R}-2,17-19$ & 0.49 & 1.20 & 0.09 & 1.16 & 0 & 0.08 \\
\hline 706-E & $115-706 \mathrm{C}-8 \mathrm{R}-1,32-35$ & 0.02 & 0.19 & 0.05 & 2.09 & 0.14 & 0.14 \\
\hline 706-E & $115-706 \mathrm{C}-8 \mathrm{R}-1,67-77$ & 0.26 & 0.08 & 0.02 & 0.34 & 0.16 & 0.07 \\
\hline 706-E & $115-706 \mathrm{C}-8 \mathrm{R}-2,44-48$ & 0.56 & 0.28 & 0 & 0.52 & 0.04 & 0.07 \\
\hline 706-E & $115-706 \mathrm{C}-8 \mathrm{R}-2,125-128$ & 0.36 & 0.19 & 0.05 & 0.21 & 0.40 & 0.14 \\
\hline 706-E & $115-706 \mathrm{C}-8 \mathrm{R}-3,45-48$ & 0.42 & 0.87 & 0.10 & 0.56 & 0.04 & 0.10 \\
\hline 706-P & $115-706 \mathrm{C}-9 \mathrm{R}-1,13-16$ & 2.93 & 3.18 & 0.12 & 2.41 & 1.17 & 0.26 \\
\hline 706-P & $115-706 \mathrm{C}-9 \mathrm{R}-1,23-29$ & 2.98 & 4.27 & 0.09 & 2.61 & 0 & 0.03 \\
\hline 706-P & $115-706 \mathrm{C}-9 \mathrm{R}-2,36-39$ & 1.48 & 0.93 & 0.05 & 0.84 & 0.10 & 0.04 \\
\hline 707-P & $115-707 \mathrm{C}-22 \mathrm{R}-1,94-98$ & 3.08 & 10.66 & 0.38 & 2.98 & 0.38 & 0.01 \\
\hline 707-P & $115-707 \mathrm{C}-22 \mathrm{R}-2,40-42$ & 3.88 & 16.89 & 0.51 & 3.22 & 0.41 & 0 \\
\hline 707-P & $115-707 C-23 R-1,123-127$ & 2.60 & 12.37 & 0.45 & 4.12 & 0.20 & 0.04 \\
\hline 707-P & $115-707 C-23 R-4,32-34$ & 4.55 & 17.18 & 0.48 & 4.48 & 0.39 & 0.03 \\
\hline 707-E & $115-707 C-25 R-1,39-43$ & 6.73 & 15.36 & 0.50 & 4.60 & 0.21 & 0.08 \\
\hline 707-E & $115-707 C-26 R-2,126-128$ & 4.81 & 22.54 & 0.62 & 4.64 & 0.25 & 0.11 \\
\hline 707-E & $115-707 C-28 R-4,133-136$ & 7.91 & 17.13 & 0.49 & 5.34 & 0.19 & 0.03 \\
\hline 713-P & $115-713 \mathrm{~A}-13 \mathrm{R}-1,63-69$ & 5.50 & 13.55 & 0.51 & 9.31 & 0.20 & 0.23 \\
\hline 713-P & $115-713 \mathrm{~A}-15 \mathrm{R}-4,7-13$ & 3.60 & 10.45 & 0.40 & 7.50 & 0.10 & 0.15 \\
\hline 713-E & $115-713 \mathrm{~A}-15 \mathrm{R}-4,143-146$ & 2.33 & 2.67 & 0.28 & 4.31 & 0.08 & 0.14 \\
\hline 713-E & $115-713 \mathrm{~A}-15 \mathrm{R}-5,90-94$ & 3.80 & 9.73 & 0.35 & 7.85 & 0.11 & 0.15 \\
\hline 713-P & $115-713 \mathrm{C}-19 \mathrm{R}-1,27-29$ & 3.80 & 13.08 & 0.50 & 9.21 & 0.12 & 0.21 \\
\hline 713-P & $115-713 A-19 R-3,12-15$ & 3.93 & 6.57 & 0.31 & 7.10 & 0.34 & 0.25 \\
\hline 713-P & $115-713 \mathrm{~A}-20 \mathrm{R}-3,51-54$ & 3.76 & 12.31 & 0.58 & 9.76 & 0.06 & 0.24 \\
\hline 713-P & $115-713 \mathrm{~A}-20 \mathrm{R}-3,112-115$ & 3.60 & 10.50 & 0.56 & 9.59 & 0.08 & 0.22 \\
\hline 713-P & $115-713 \mathrm{~A}-20 \mathrm{R}-3,137-139$ & 3.57 & 17.97 & 0.46 & 21.55 & 0.10 & 0.21 \\
\hline 713-P & $115-713 \mathrm{~A}-20 \mathrm{R}-5,127-130$ & 3.31 & 13.20 & 0.78 & 8.67 & 0.22 & 0.22 \\
\hline 713-P & $115-713 \mathrm{~A}-21 \mathrm{R}-3,55-59$ & 4.74 & 13.17 & 0.58 & 13.02 & 0.22 & 0.28 \\
\hline 715-UE & $115-715 \mathrm{~A}-23 \mathrm{R}-3,91-95$ & 0.40 & 2.20 & 0.04 & 8.31 & 0.09 & 0.03 \\
\hline 715-UE & $115-715 \mathrm{~A}-24 \mathrm{R}-2,30-38$ & 0.20 & 2.66 & 0.02 & 12.17 & 0.02 & 0.02 \\
\hline 715-UP & $115-715 \mathrm{~A}-25 \mathrm{R}-3,25-34$ & 6.06 & 8.82 & 0.36 & 28.55 & 0.43 & 0.41 \\
\hline 715-UP & 115-715A-25R-6, 38-47 & 14.08 & 13.17 & 0.39 & 32.06 & 0.45 & 0.26 \\
\hline 715-UP & $115-715 \mathrm{~A}-29 \mathrm{R}-1,33-38$ & 0.60 & 8.43 & 0.33 & 20.41 & 0.38 & 0.15 \\
\hline 715-LE & $115-715 \mathrm{~A}-29 \mathrm{R}-1,113-119$ & 3.74 & 7.01 & 0.28 & 2.54 & 0.14 & 0.02 \\
\hline 715-LP & $115-715 \mathrm{~A}-29 \mathrm{R}-2,42-48$ & 1.78 & 16.53 & 0.70 & 7.79 & 0.22 & 0.20 \\
\hline 715-LP & $115-715 \mathrm{~A}-30 \mathrm{R}-1,52-61$ & 1.34 & 3.67 & 0.31 & 5.26 & 0.20 & 0.12 \\
\hline 715-LP & $115-715 A-30 R-3,41-51$ & 0.89 & 2.82 & 0.36 & 3.21 & 0.25 & 0.13 \\
\hline 715-LP & 115-715A-30R-6, 0-9 & 1.78 & 4.77 & 0.28 & 4.95 & 0.28 & 0.15 \\
\hline 715-LP & 115-715A-3IR-2, 89-94 & 0.54 & 5.39 & 0.24 & 4.30 & 0.25 & 0.12 \\
\hline Blank & & 0.70 & 0.61 & 0.04 & 0.26 & 0.03 & 0.01 \\
\hline DL & & 0.20 & 0.15 & 0.01 & 0.08 & 0.10 & 0.02 \\
\hline
\end{tabular}

Note: $\mathrm{DL}=$ detection limit.

tions of the groundmass and compose $\leq 25 \%$ of each sample. The absence of pillows and the abundance of vesicles indicate subaerial or very shallow-water formation of Site 707 basalts.

Basalts from Site 713 are interbedded with chalks containing middle Eocene nannofossils and are dated radiometrically at 48 Ma (Duncan and Hargraves, this volume). Group 713-P samples come from Cores 115-713A-13R, -15R, and -19R through $-21 \mathrm{R}$ ( 9 samples). They contain $5 \%-15 \%$ plagioclase ( $\leq 2 \mathrm{~mm}$ ) and $5 \%-10 \%$ augite $(<1 \mathrm{~mm})$ phenocrysts (locally glomerocrysts), and display medium- to fine-grained, subophitic, and, in some cases, intersertal textures. Vesicles are rare $(<2 \%)$ and filled with fibrous zeolites, gray clay minerals, and rarely calcite. Chlorite and clay minerals $(\leq 40 \%)$ replace glass and matrix minerals in all samples.

Group 713-E samples (2 analyzed, Core 115-713A-15R) contain phenocrysts and locally glomerocrysts of augite $(5 \%,<0.8$ $\mathrm{mm})$ and slightly aligned plagioclase $(15 \%,<1 \mathrm{~mm})$. In other respects, they resemble Group 713-P rocks. Intercalation of marine sediments with the vesicular basalts at Site 713 indicates extrusion at shallow-water depths.
Although four groups of early Paleogene (55-60 Ma) basalts (dated paleontologically from overlying reef limestones and radiometrically by Duncan and Hargraves, this volume) can be distinguished on the basis of $\mathrm{Fe} / \mathrm{Mg}$ ratios and other chemical factors at Site 715 , all basalts are petrographically similar. They are largely aphyric (augite and plagioclase phenocrysts $<3 \%$ ), with olivine (usually altered) abundant in Group 715-UP basalts (up to $10 \%$ ). Samples show subophitic and, near flow tops, vesicular (up to $50 \%$ ) textures, with typically $20 \%$ of the rock consisting of pale green (celadonite?) to brown clay minerals and chlorite that replace matrix minerals and glass and, together with calcite, fill vesicles. Lateritic oxidation and weathering at the tops of flows indicates that the basalts are subaerial. One chemically analyzed sample $(115-715 \mathrm{~A}-23 \mathrm{R}-3,91-95 \mathrm{~cm})$ is lateritized.

\section{SAMPLE PREPARATION AND ANALYTICAL METHODS}

The same powders used for major and trace element analyses on the JOIDES Resolution were used for noble metal analyses. Powders were prepared from vesicle-poor and fairly alterationfree portions of core. Cut surfaces were abraded on a diamond lap and ultrasonically cleaned with methanol and distilled water. After crushing in a hydraulic press, chips were powdered in a tungsten-carbide mill.

Noble metal analyses were determined by ICP-MS on $10 \%$ aqua regia solutions after NiS fire assay preconcentration of 10 $\mathrm{g}$ of rock powder. Reagent blanks are $0.70,0.61,0.04,0.26$, 0.03 , and $0.01 \mathrm{ppb}$ for $\mathrm{Au}, \mathrm{Pd}, \mathrm{Rh}, \mathrm{Pt}, \mathrm{Ru}$, and $\mathrm{Ir}$, respectively, and were subtracted from the concentrations reported. Average "detection limits" ( $3 \sigma$, above background) are equivalent to $0.20,0.15,0.01,0.08,0.10$, and 0.02 ppb rock, respectively. Details of the procedure are being prepared for publication (S. Jackson, pers. comm., 1989). Replicate analyses of the standard SARM-7 have yielded values of $245,1452,227,3923,380$, and $77 \mathrm{ppb}$ for $\mathrm{Au}, \mathrm{Pd}, \mathrm{Rh}, \mathrm{Pt}, \mathrm{Ru}$, and $\mathrm{Ir}$, respectively, with relative standard deviations of $7 \%$ or better for all elements. All values are within $10 \%$ of the certified concentrations except for $\mathrm{Au}$, which is $20 \%$ low.

\section{ANALYTICAL RESULTS}

\section{Major and Trace Element Data}

Major and trace element data appear in Figures 2 and 3 with average group compositions in Table 2 . Site 715 basalts show the highest $\mathrm{MgO}$ contents and Site 706 basalts the lowest (Fig. 2). Aluminum concentrations tend to decrease or remain constant with decreasing $\mathrm{MgO}$ contents at all sites, whereas $\mathrm{TiO}_{2}$ increases. Group 706-P basalts display the highest $\mathrm{Al}_{2} \mathrm{O}_{3}$ concentrations, and Group 706-E, low $\mathrm{Al}_{2} \mathrm{O}_{3}$ concentrations and very high $\mathrm{TiO}_{2}$. These characteristics indicate that plagioclase fractionation was important in magma evolution at all four sites and that $\mathrm{TiO}_{2}$ behaved as an incompatible element.

Abundant plagioclase phenocrysts in basalts from all sites except Site 715 corroborate these suggestions and indicate a similarity to MORB. Indeed, these hypersthene normative (calculated assuming $\mathrm{Fe}^{3+} / \mathrm{Fe}^{2+}=0.15$ ) tholeiites show more chemical similarities with MORB than with most OIB. Their $\mathrm{K}_{2} \mathrm{O}$ and $\mathrm{TiO}_{2}$ contents are lower and $\mathrm{Al}_{2} \mathrm{O}_{3}$ contents generally higher than in comparably evolved oceanic-island tholeiites such as in Hawaii (cf. Basaltic Volcanism Study Project [BVSP], 1981, pp. 161-192). Average major element compositions for Sites 707 and 713 show amazing similarities with average MORB compositions from Melson et al. (1976).

When plotted vs. the incompatible element $\mathrm{Zr}$, both $\mathrm{Ni}$ and $\mathrm{Cr}$ display compatible behavior in Site 707 and 715 basalts and, 

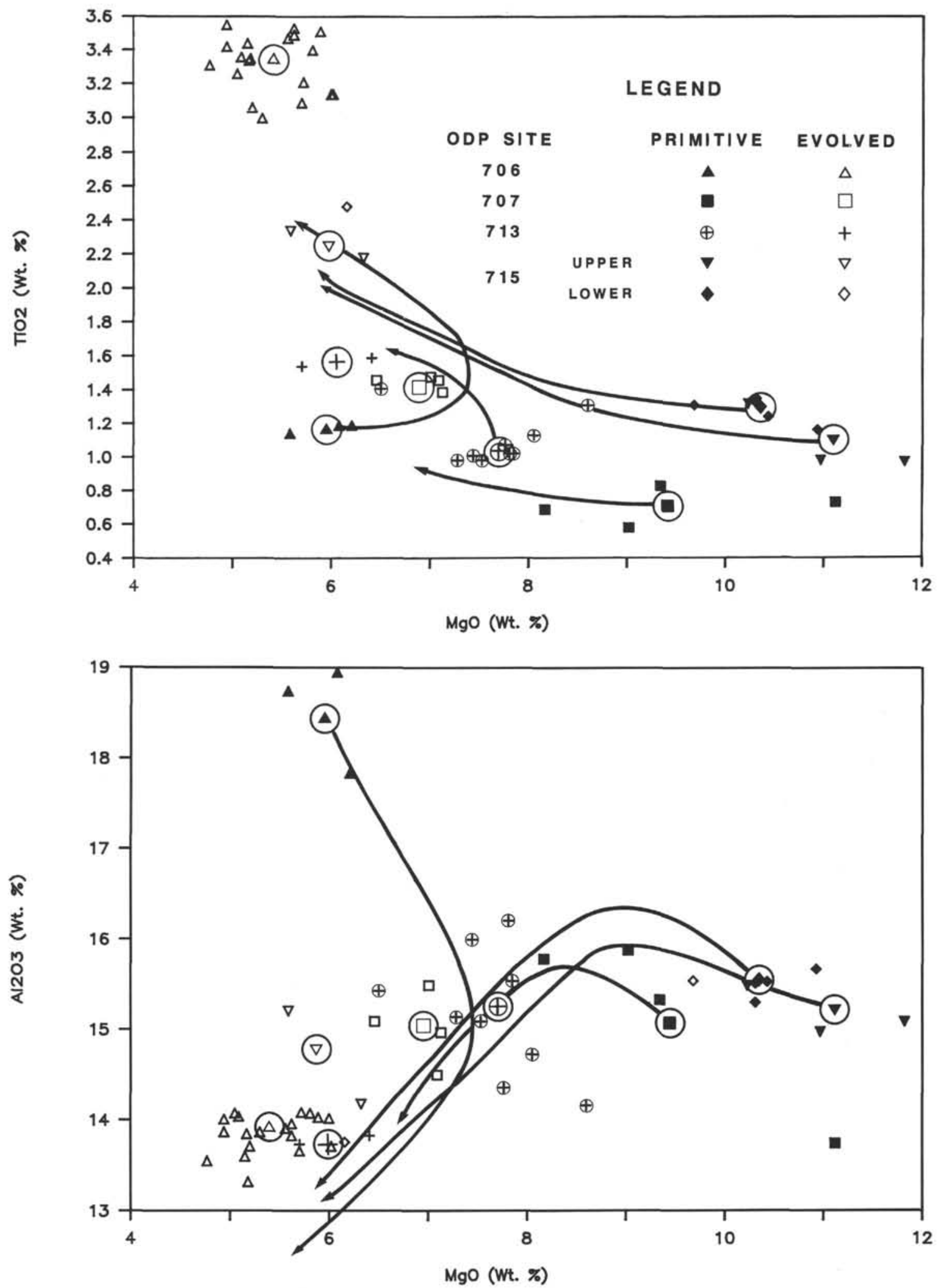

Figure 2. $\mathrm{Al}_{2} \mathrm{O}_{3}$ and $\mathrm{TiO}_{2}$ concentrations vs. $\mathrm{MgO}$ in Leg 115 basalts (all concentrations in wt $\%$ volatile free) from Sites 706 , 707,713 , and 715 . Average concentrations for each magma group are circled. Curves show the predicted fractional crystallization paths for each magma group from the Nathan and Van Kirk (1978) model. Data are from Backman, Duncan, et al. (1988). 

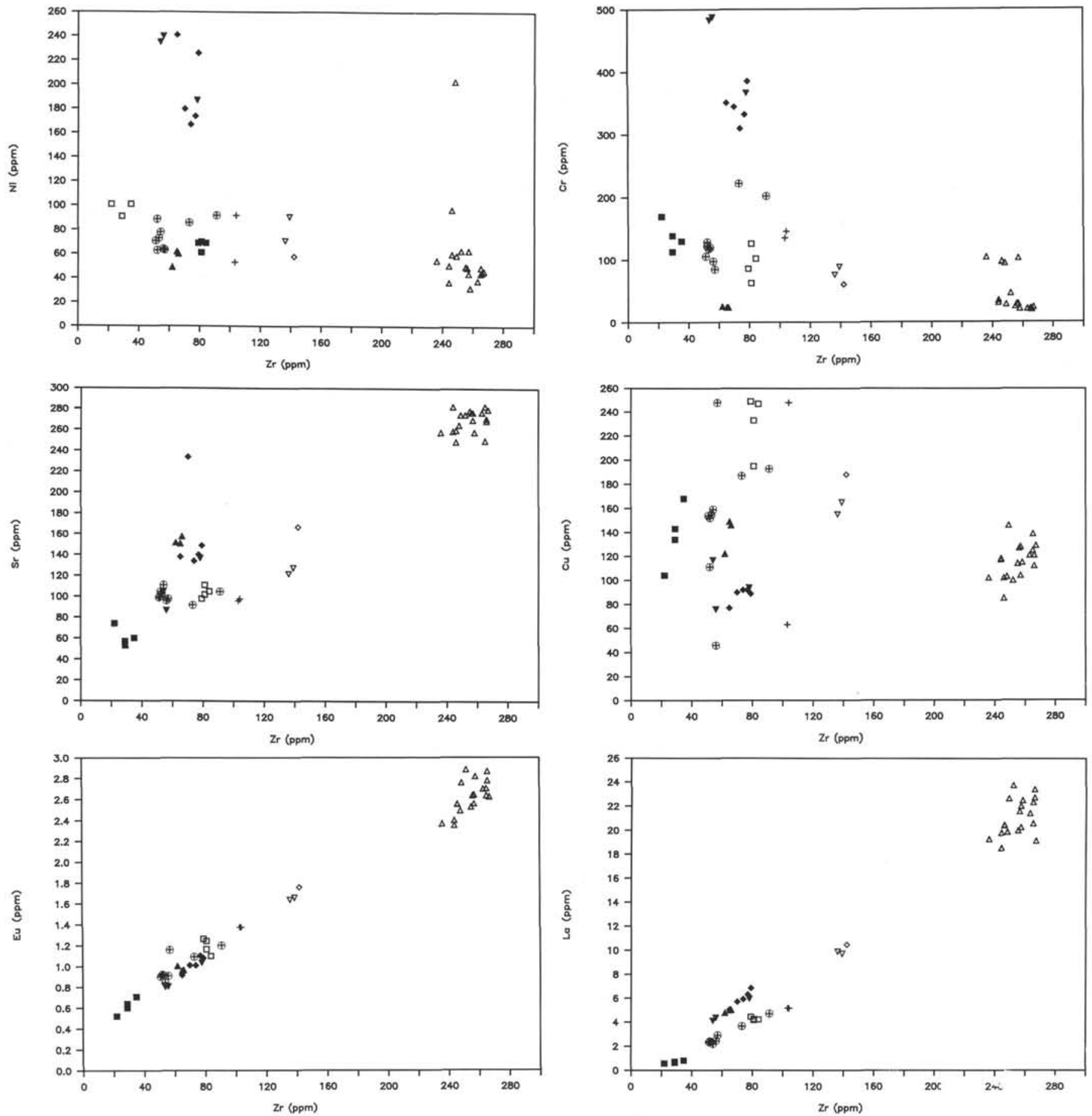

Figure 3. Selected trace elements (ppm) plotted vs. $\mathrm{Zr}(\mathrm{ppm}$ ) for Sites 706, 707, 713, and 715. Data are from Backman, Duncan, et al. (1988) and our unpublished data ( $\mathrm{La}$ and $\mathrm{Eu}$ ). Symbols are as in Figure 2.

to a lesser extent, in Site 706 basalts. Site 713 data, however, show no clear trends (Fig. 3). Concentrations of $\mathrm{Cu}$, on the other hand, increase with $\mathrm{Zr}$ in Site 707 and 715 basalts, remain constant in Site 706 basalts, and display no coherent behavior in Site 713 basalts. Rubidium varies from 1 to $42 \mathrm{ppm}$ in Group 706-E basalts but shows no correlation with other incompatible elements. Alkalinity indicators such as $\mathrm{Nb} / \mathrm{Y}$ and $\mathrm{La} / \mathrm{Sm}$ (Fig. 5) ratios indicate that all the rocks are tholeiitic (Pearce and Cann, 1973), with Site 713 and particularly Site 707 ratios very similar to "normal" Type-1 MORB (Bryan et al., 1977; Langmuir et al., 1977). Sites 706 and 715 show ratios equivalent to "unenriched" tholeiitic basalts from oceanic-island volcanoes such as Mauna Loa in Hawaii (BVSP, 1981, p. 172). The ratios are only constant for Site 715 basalts, which demonstrates that basalts from the other sites cannot be comagmatic (or cannot be related by low-pressure fractionation processes) because no known low-pressure basaltic phenocryst phases can appreciably fractionate these elements (Schilling, 1971; Frey et al., 1974). 


\begin{tabular}{|c|c|c|c|c|c|c|c|c|c|c|c|c|c|c|c|}
\hline $\begin{array}{c}\text { Group } \\
N\end{array}$ & $\begin{array}{c}706-P \\
3\end{array}$ & $\begin{array}{l}\text { 706-E } \\
19(17)\end{array}$ & $\begin{array}{l}\text { Model } \\
706-\mathrm{E}\end{array}$ & $\begin{array}{c}707-P \\
4\end{array}$ & $\begin{array}{c}\text { 707-E } \\
4(3)\end{array}$ & $\begin{array}{l}\text { Model } \\
707-E\end{array}$ & $\begin{array}{c}713-P \\
9\end{array}$ & $\begin{array}{c}713-E \\
2\end{array}$ & $\begin{array}{l}\text { Model } \\
713-E\end{array}$ & $\underset{3}{715-U P}$ & $\begin{array}{c}715-\mathrm{UE} \\
2\end{array}$ & $\begin{array}{c}\text { Model } \\
715-\text { UE }\end{array}$ & $\underset{5}{715-L P}$ & $\begin{array}{c}715-\mathrm{LE} \\
1\end{array}$ & $\begin{array}{l}\text { Model } \\
715-\mathrm{LE}\end{array}$ \\
\hline \multicolumn{16}{|c|}{${ }^{a, c}{ }_{\text {Major elements (wt } \% \text { ): }}$} \\
\hline $\mathrm{SiO}_{2}$ & 49.51 & 48.73 & 49.56 & 50.75 & 50.18 & 51.70 & 50.02 & 49.87 & 49.90 & 48.50 & 48.16 & 48.44 & 48.41 & 49.76 & 49.86 \\
\hline $\mathrm{TiO}_{2}$ & 1.18 & 3.35 & 2.23 & 0.70 & 1.45 & 0.84 & 1.11 & 1.57 & 1.49 & 1.10 & 2.29 & 2.01 & 1.28 & 2.50 & 2.07 \\
\hline $\mathrm{Al}_{2} \mathrm{O}_{3}$ & 18.54 & 13.95 & 14.24 & 15.09 & 15.07 & 15.06 & 15.25 & 13.82 & 13.88 & 15.31 & 14.90 & 15.09 & 15.61 & 13.86 & 13.91 \\
\hline $\mathrm{FeO}$ & 8.91 & 14.10 & 14.67 & 11.00 & 12.34 & 12.00 & 10.55 & 13.25 & 13.34 & 10.75 & 14.99 & 15.21 & 10.93 & 12.79 & 12.88 \\
\hline $\mathrm{MnO}$ & 0.14 & 0.20 & 0.23 & 0.11 & 0.17 & 0.10 & 0.19 & 0.24 & 0.22 & 0.18 & 0.20 & 0.23 & 0.18 & 0.21 & 0.21 \\
\hline $\mathrm{MgO}$ & 5.97 & 5.45 & 5.44 & 9.34 & 6.95 & 6.96 & 7.68 & 6.07 & 6.11 & 11.09 & 6.04 & 6.08 & 10.40 & 6.20 & 6.19 \\
\hline $\mathrm{CaO}$ & 13.20 & 10.35 & 10.67 & 10.74 & 11.42 & 10.84 & 12.81 & 12.20 & 12.34 & 11.07 & 10.18 & 10.36 & 10.46 & 11.47 & 11.53 \\
\hline $\mathrm{Na}_{2} \mathrm{O}$ & 2.22 & 2.65 & 2.27 & 2.12 & 2.23 & 2.31 & 2.12 & 2.28 & 2.33 & 1.66 & 2.47 & 1.87 & 2.01 & 2.47 & 2.18 \\
\hline $\mathrm{K}_{2} \mathrm{O}$ & 0.23 & 0.83 & 0.48 & 0.12 & 0.09 & 0.15 & 0.19 & 0.55 & 0.28 & 0.22 & 0.52 & 0.45 & 0.58 & 0.49 & 0.95 \\
\hline $\mathrm{P}_{2} \mathrm{O}_{5}$ & 0.10 & 0.39 & 0.22 & 0.03 & 0.11 & 0.04 & 0.07 & 0.14 & 0.10 & 0.12 & 0.24 & 0.26 & 0.13 & 0.25 & 0.22 \\
\hline $\mathrm{Mg}^{\prime}$ & 0.57 & 0.43 & & 0.63 & 0.53 & & 0.59 & 0.48 & & 0.67 & 0.44 & & 0.65 & 0.49 & \\
\hline \multicolumn{16}{|c|}{$\mathrm{b}, \mathrm{c}$ Trace elements (ppm): } \\
\hline $\mathrm{Cr}_{\mathrm{r}}$ & 24.3 & 45.6 & 12 & 138 & 94 & 86 & 134 & 141 & 43 & 446 & 82 & 71 & 345 & 61 & 283 \\
\hline $\mathrm{Ni}$ & 57.0 & 57.5 & 41 & 96 & 67 & 38 & 75 & 72 & 45 & 221 & 81 & 26 & 198 & 58 & 26 \\
\hline $\mathrm{Cu}$ & 139 & 115 & 291 & 137 & 231 & 177 & 156 & 156 & 235 & 96 & 160 & 203 & 88 & 188 & 145 \\
\hline $\mathrm{Sr}$ & 163 & 280 & 147 & 62 & 110 & 67 & 105 & 102 & 111 & 107 & 134 & 130 & 164 & 172 & 174 \\
\hline $\mathrm{Y}$ & 20.7 & 42.9 & 43 & 17.5 & 29.5 & 29 & 23.9 & 35.0 & 36 & 19.3 & 38.5 & 41 & 21.8 & 38.0 & 36 \\
\hline $\mathrm{Zr}$ & 64.0 & 255. & 133 & 28.8 & 81.2 & 37 & 59.9 & 103.5 & 89 & 62.7 & 138.5 & 133 & 73.0 & 142 & 121 \\
\hline $\mathrm{Nb}$ & 5.7 & 14.3 & 12 & 1.0 & 1.5 & 1.3 & 1.9 & 2.5 & 2.8 & 5.0 & 10.5 & 10.5 & 7.4 & 11 & 12 \\
\hline $\mathrm{La}$ & 4.95 & 21.1 & 9.4 & 0.68 & 4.28 & 0.86 & 2.84 & 5.18 & 4.1 & 4.84 & 9.84 & 9.6 & 5.97 & 10.5 & 9.4 \\
\hline Sm & 2.54 & 7.72 & 4.9 & 1.27 & 5.11 & 1.6 & 2.37 & 3.56 & 3.4 & 2.27 & 4.52 & 4.4 & 2.71 & 5.03 & 4.3 \\
\hline Eu & 0.98 & 2.62 & 1.6 & 0.62 & 1.20 & 0.75 & 0.99 & 1.38 & 1.3 & 0.88 & 1.65 & 1.5 & 1.02 & 1.76 & 1.5 \\
\hline \multicolumn{16}{|l|}{ Noble metals (ppb): } \\
\hline $\mathrm{Au}$ & 2.46 & 0.55 & & 3.53 & 6.48 & & 3.98 & 3.06 & & 6.91 & 0.30 & & 1.27 & 3.74 & \\
\hline Pd & 2.79 & 0.81 & & 14.3 & 18.4 & & 12.3 & 6.20 & & 10.2 & 2.43 & & 6.64 & 7.01 & \\
\hline $\mathrm{Rh}$ & 0.09 & 0.07 & & 0.46 & 0.54 & & 0.52 & 0.32 & & 0.36 & 0.03 & & 0.38 & 0.28 & \\
\hline $\mathrm{Pt}$ & 1.95 & 1.18 & & 3.70 & 4.86 & & 10.6 & 6.08 & & 27.0 & 10.2 & & 5.10 & 2.54 & \\
\hline Ru & 0.42 & 0.09 & & 0.35 & 0.22 & & 0.16 & 0.09 & & 0.42 & 0.05 & & 0.24 & 0.14 & \\
\hline Ir & 0.11 & 0.11 & & 0.02 & 0.07 & & 0.22 & 0.15 & & 0.27 & 0.03 & & 0.14 & 0.02 & \\
\hline \multicolumn{16}{|l|}{ Element ratios: } \\
\hline $\mathrm{Pd} / \mathrm{Pt}_{\mathrm{t}}$ & 1.43 & 0.69 & & 3.86 & 3.79 & & 1.16 & 1.02 & & 0.38 & 0.24 & & 1.30 & 2.76 & \\
\hline $\mathrm{Pd} / \mathrm{Ir}$ & 25.4 & 7.36 & & 715 & 263 & & 55.9 & 41.3 & & 37.8 & 81.0 & & 47.4 & 351 & \\
\hline $\mathrm{Ru} / \mathrm{Ir}$ & 3.82 & 0.82 & & 17.5 & 3.14 & & 0.73 & 0.6 & & 1.56 & 1.7 & & 1.71 & 7.0 & \\
\hline $\mathrm{La} / \mathrm{Sm}$ & 1.95 & 2.74 & & 0.54 & 0.84 & & 1.20 & 1.46 & & 2.13 & 2.18 & & 2.20 & 2.09 & \\
\hline $\mathrm{Nb} / \mathrm{Y}$ & 0.28 & 0.33 & & 0.057 & 0.051 & & 0.079 & 0.071 & & 0.26 & 0.27 & & 0.34 & 0.29 & \\
\hline \multicolumn{16}{|l|}{ a'Modeling data: } \\
\hline Olivine & & & $0.072(1)$ & & & $0.309(2)$ & & & $0.096(1)$ & & & $0.231(2)$ & & & $0.379(1)$ \\
\hline Augite & & & $0.178(3)$ & & & $0.223(4)$ & & & $0.359(4)$ & & & $0.298(4)$ & & & $0.037(4)$ \\
\hline Plagioclase & & & $0.750(5)$ & & & $0.468(6)$ & & & $0.545(6)$ & & & $0.471(6)$ & & & $0.584(6)$ \\
\hline$\%$ Crystallized & & & 52 & & & 22 & & & 33 & & & 53 & & & 40 \\
\hline$R^{2}$ & & & 2.775 & & & 3.144 & & & 0.116 & & & 0.656 & & & 0.500 \\
\hline
\end{tabular}

Notes: Major element oxides are given in wt \%, normalized to $100 \%$ volatile free. Total $\mathrm{Fe}$ as $\mathrm{FeO} . \mathrm{N}=$ number of smples with number for $\mathrm{PGE}$ data in parenthese. $\mathrm{Mg}^{\prime}=\mathrm{Mg} /(\mathrm{Mg}+0.9 \mathrm{Fe})$ atomic. Major elements are modeled by means of mass balance calculations. Proportions of phases removed are shown under the modeling data, and the number in brackets corresponds to the mineral analysis used in the calculation, as follows: numbers 1, 2, and 3: analyses 22 and 13 and analysis 7 from BVSP, 1981, pp. 181 and 183, respectively; numbers 4 and 5: analyses 10 (augite) and 7 (plagioclase)
from Frey et al., 1974; and number 6: analysis 4 (plagioclase) from Bryan et al., 1977.

${ }^{6}$ Trace elements are modeled by using phase proportions and $\%$ crystallization indicated from mass balance calculations. Partitioning coefficients are for $\mathrm{Cr}, \mathrm{Ni}, \mathrm{Cu}, \mathrm{Sr}, \mathrm{Y}, \mathrm{Zr}, \mathrm{Nb}, \mathrm{La}, \mathrm{Sm}$, and $\mathrm{Eu}$ in olivine $2.0-2.7,13,0,0.01,0.01,0.01,0.01,0.01,0.01$, and 0.02 ; augite $10.0,2.75,0,0.08,0.01,0.01,0.01,0.08,0.30$, and 0.35 ; and plagioclase $0.01,0.04,0,1.5,0.02,0.02,0.02,0.15,0.08$, and 0.34. Partitioning coefficients compiled from Evans (1978). Frey et al. (1974), and Philpotts and Schnetzler (1970).

Major elements and $\mathrm{Cr}, \mathrm{Ni}, \mathrm{Cu}, \mathrm{Sr}, \mathrm{Zr}$, and $\mathrm{Nb}$ data for average of samples in Table 1 were compiled from Backman, Duncan, et al. (1988). La, Sm, and Eu = our unpublished data determined by ICPMS at The Memorial University of Newfoundland, Canada. 


\section{Noble Metal Concentrations}

Noble metal abundances (Table 1; group averages, Table 2) are plotted in Figures 4 and 5 (there are three fewer samplestwo from Site 706, one from 707-than in Fig. 3 as a result of analytical mishaps). Concentrations of $\mathrm{Au}$ and $\mathrm{Pd}$ (Table 2) are highest in Group 707-E (average $=6.5$ and $18 \mathrm{ppb}$ ) and lowest in Groups 715 -UE and 706-E basalts ( 0.3 and $0.8 \mathrm{ppb})$. One Group 715-UP sample shows anomalously high Au concentrations (Fig. 4). Gold and palladium concentrations resemble those reported for OIB (Table 3), but Group 707-E values are the highest yet noted in OIB and MORB. Most MORB Au and Pd values reported by Hertogen et al. (1980) are much lower $(\sim 0.2$ and $\leq 0.4 \mathrm{ppb}$ ), but samples of these elements from Indian Ocean spreading centers display similar concentrations ( 3.5 and $5.7 \mathrm{ppb}$ ) to Leg 115 hotspot basalts.

Rhodium (Table 2) shows the highest concentrations in Group 707-E basalts $(0.54 \mathrm{ppb})$ and the lowest concentrations in Group 715 -UE lavas $(0.03 \mathrm{ppb})$. Group $706-\mathrm{E}$ basalts have the lowest Pt concentrations (1.2), and Group 715-UP by far the highest $(27 \mathrm{ppb})$; the composite average for the basalts is $7.3 \mathrm{ppb}$. Comparison data for $\mathrm{Rh}$ and $\mathrm{Pt}$ in oceanic basalts are nonexistent.

Average Ru concentrations (Table 2 ) vary from $\sim 0.42 \mathrm{ppb}$ (Group 715-UP) to $0.05 \mathrm{ppb}$ (Group 715-UE). Group 715-UP basalts display the highest average (but concentrations are variable) Ir concentration $(0.27 \mathrm{ppb})$, and Groups $707-\mathrm{P}$ and $715-\mathrm{LE}$ the lowest concentrations $(0.02 \mathrm{ppb})$. Composite group averages for $\mathrm{Ru}$ and $\mathrm{Ir}$ are 0.22 and $0.11 \mathrm{ppb}$, respectively (Table 3 ). Indian MORBs show very similar Ir concentrations to average Leg 115 basalts, but most MORBs have much lower concentrations $(\leq 0.035 \mathrm{ppb})$, and other oceanic-island tholeiites slightly higher average values $(0.25 \mathrm{ppb})$.

Plots of the noble metals vs. the differentiation index $\mathrm{Mg}^{\prime}$ $\left(\mathrm{Mg}^{\prime}=\mathrm{Mg} /\left[\mathrm{Mg}+\left(0.9 \times\left[\mathrm{Fe}^{2+}+\mathrm{Fe}^{3+}\right]\right)\right]\right.$ atomic $)$ indicate their tendency toward compatible behavior because average concentrations at most sites either decrease with decreasing $\mathrm{Mg}^{\prime}$ (i.e., they decrease with increasing differentiation) or they show little or no change (Fig. 4). Exceptions include $\mathrm{Au}$ and $\mathrm{Pd}$ in Site 707 basalts and the lower basalts at Site 715, as well as Rh and $\mathrm{Ir}$ in Site 707 basalts. Such PGE ratios as $\mathrm{Pt} / \mathrm{Pd}, \mathrm{Pd} / \mathrm{Ir}$, and $\mathrm{Ru} / \mathrm{Ir}$ remain fairly constant in each magma group with changing $\mathrm{Mg}^{\prime}$. Palladium/iridium ratios are very high in Leg 115 basalts (particularly Site 707) compared with other oceanicisland tholeiitic magmas, but they appear similar to MORB (Table 3).

Indicators of alkalinity such as $\mathrm{La} / \mathrm{Sm}$ (Fig. 5) imply that $\mathrm{Au}, \mathrm{Pd}, \mathrm{Rh}$, and $\mathrm{Ru}$ abundances decrease with increasing alkalinity (i.e., increasing $\mathrm{La} / \mathrm{Sm}$ ratios), although these trends do not take into account differentiation effects. Platinum and iridium show no clear dependency on $\mathrm{La} / \mathrm{Sm}$ ratios, but $\mathrm{Pt} / \mathrm{Pd}$ ratios tend to decrease, $\mathrm{Pd} / \mathrm{Ir}$ ratios decrease, and $\mathrm{Ru} / \mathrm{Ir}$ ratios remain constant with increasing alkalinity.

All of the noble metals can be mobile under certain types of metasomatic/hydrothermal conditions (e.g., Macdonald, 1987; Barnes et al., 1985), but there is little evidence for their mobility in our Leg 115 basalt samples. One of the Group 715-UP samples shows anomalous $\mathrm{Au}$ concentrations (Fig. 4). It also has slightly higher $\mathrm{Rb}(5 \mathrm{ppm})$ and $\mathrm{Cu}$ concentrations $(120 \mathrm{ppm})$ compared with the other two Group 715-UP samples ( 2 and $\sim 85 \mathrm{ppm}$, respectively), so the possibility that Au was added to this sample cannot be eliminated. There is little or no relationship between noble metal concentrations at each site and various indicators of alteration such as LOI or alkali metal concentrations.

Samples selected for geochemical analysis from Site 706 show the greatest range of mineralogical and geochemical alteration effects, as detailed in Greenough et al. (this volume). Despite this, when variations in the primary geochemistry of the rocks are taken into consideration, it is clear that much of the variation in noble metal concentrations and element ratios can be related to primary processes (and analytical uncertainty) as opposed to alteration processes. Low-grade alteration has a randomizing effect on element concentrations as rocks tend to be variably altered. Figures 4 and 5 show that, with but a few minor exceptions, the noble metals vary regularly with geochemical indicators of magma fractionation and alkalinity. Therefore, it is unlikely that alteration had any major effect on noble metal concentrations in most of the Leg 115 basalt samples used in this study.

\section{GENETIC RELATIONSHIPS BETWEEN MAGMAS}

At most sites, variations in incompatible element ratios (e.g., Fig. 5) show that the basalts are not likely comagmatic, so it is necessary to obtain some appreciation for how closely they approach (or how much they depart from) a comagmatic ideal before interpreting the noble metal data. Mass balance calculations (Bryan et al., 1969) provide estimates of the mineral phases and proportions possibly removed during fractionation at each site. Only phenocryst phases observed in the basalts were used in the calculations. Analyses of phenocrysts in Leg 115 basalts were not available, so various analyses from MORB and OIB were used with analyses producing the best mix (lowest $R^{2}$ ) reported in Table 2 .

The $\mathrm{R}^{2}$ values (Table 2 ) indicate that evolved basalts can most easily be derived from primitive basalts at Sites 713 and $715\left(\mathrm{R}^{2}<1\right)$. Basalts from Sites 706 and 707 depart farthest from the comagmatic ideal. Major elements that fit the mixing model the worst are those associated with magma alkalinity (e.g., $\mathrm{TiO}_{2}$ and $\mathrm{K}_{2} \mathrm{O}$; cf. Group 706-E with Model 706-E and Group 707-E with Model 707-E). Phase proportions and crystallization percentages (from mass balance) were used in trace element modeling (Table 2), assuming Rayleigh fractionation (Gast, 1968). In general, trace element modeling confirms the results of mass balance calculations (Table 2).

Curves in Figure 2 show the predicted behavior of selected major elements for each primitive magma group from the Nathan and Van Kirk (1978) magma crystallization model. The curves end (denoted by arrows) at the percentage of crystallization required (from mass balance) to produce evolved rocks from primitive rocks. Although information on fractionation lacks pressures (model applies to low pressure) and considering that crystallization always exceeds $20 \%$ (model loses accuracy beyond this percentage), it is amazing how closely the model predicts evolved compositions. Although magmas at each site may not be comagmatic, we think that these calculations demonstrate a close kinship. Considering the mass balance and trace element modeling results, primitive-to-evolved magma pairs can be subjectively ordered according to how closely they approach a comagmatic model, as follows: 715-UP $\rightarrow$ 715-UE (most closely); 715-LP $\rightarrow$ 715-LE; 713-P $\rightarrow$ 713-E; 706-P $\rightarrow$ 706-E; and 707-P $\rightarrow 707-\mathrm{E}$ (greatest departure). In the following discussion, lavas at each site are considered comagmatic; however, the integrity of that assumption, and the conclusions derived from it, should be tempered according to the order of the magma pairs listed above.

\section{BEHAVIOR OF NOBLE METALS DURING MAGMA EVOLUTION}

Noble metal abundances tend to decrease with increasing fractionation in many mafic magmas, but the process or processes responsible for these concentration decreases remain a subject of debate (e.g., Brugmann et al., 1987). In part, confusion over the merits of various processes probably stems from the fact that so many studies to date have concentrated on rocks associated with PGE ore deposits where exceptional conditions 

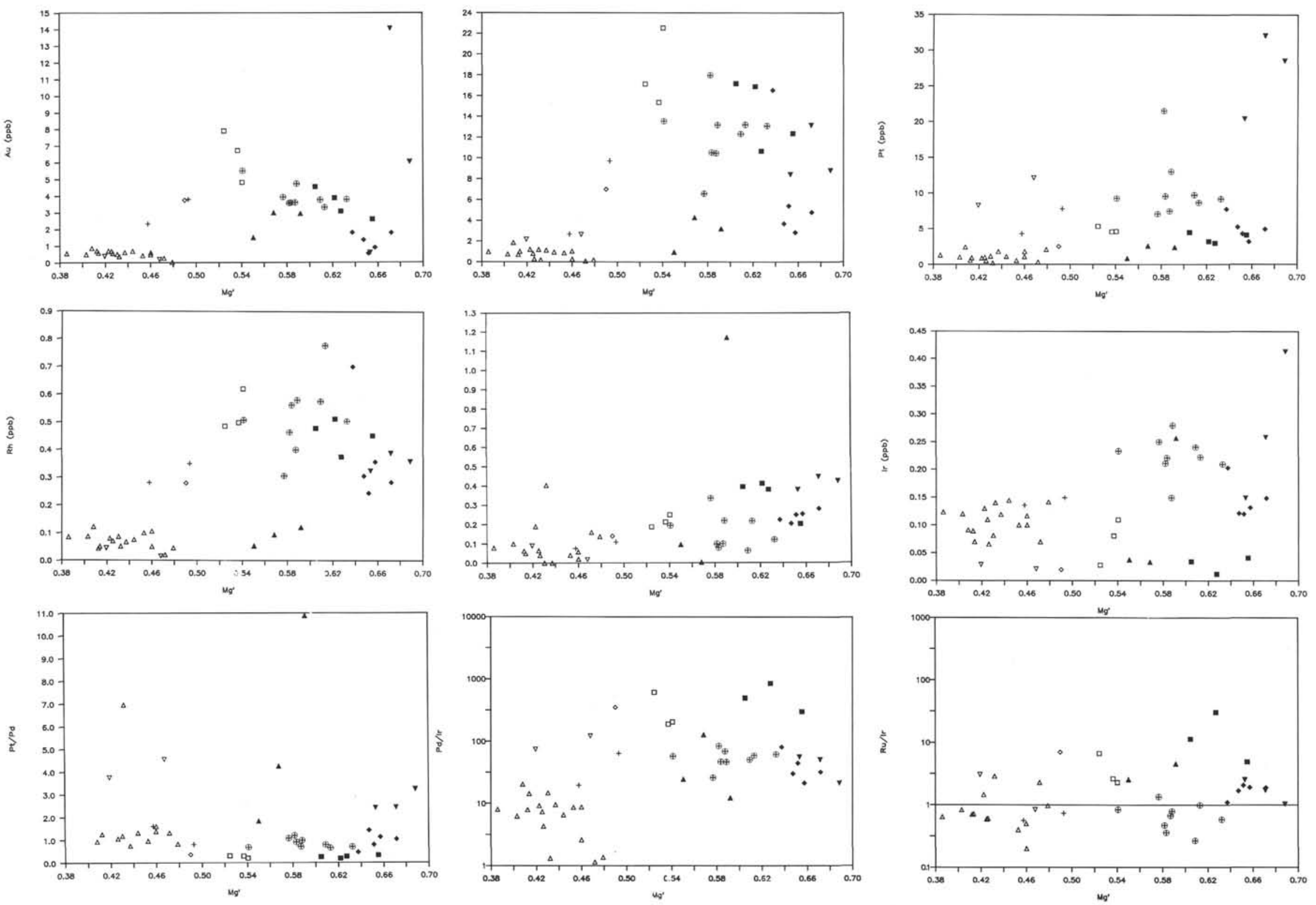

Figure 4. Noble metal abundances (ppb) and ratios in Leg 115 basalts plotted vs. $\mathrm{Mg}^{\prime}\left(\mathrm{Mg}^{\prime}=\mathrm{Mg} /[\mathrm{Mg}+(0.9 \times\right.$ total Fe) atomic]) for Sites $706,707,713$, and 715 . Symbols are as in Figure 2 . 

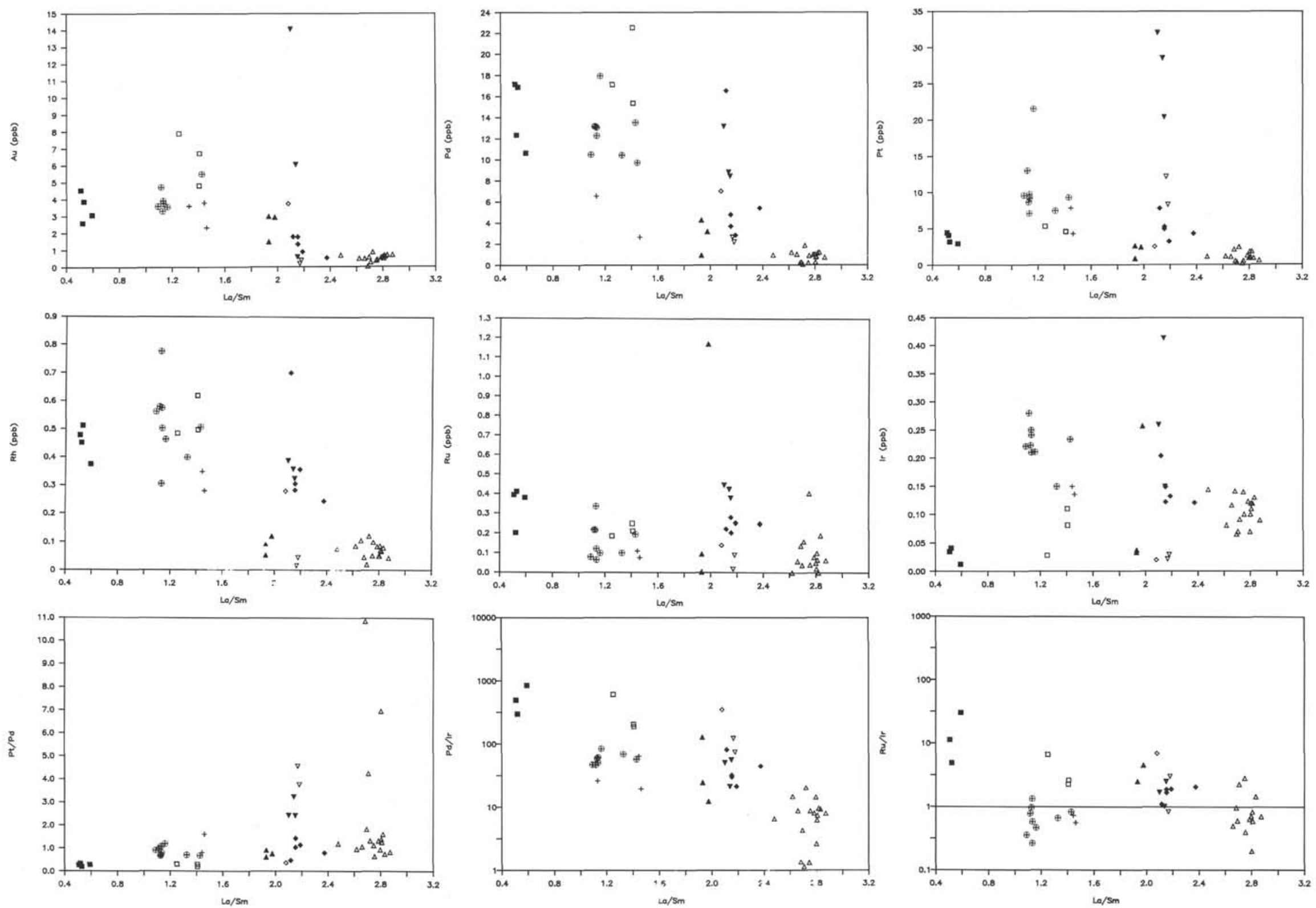

Figure 5. Noble metal abundances (ppb) and ratios in Leg 115 basalts plotted vs. La/Sm ratios ( $\mathrm{La} / \mathrm{Sm}$ from our unpubl. data) for Sites 706, 707, 713, and 715. Symbols are as in Figure 2. 
Ross and Keays, 1979; Crocket, 1981; Naldrett, 1981; Barnes and Naldrett, 1985). Observations on glasses and the S content of mafic magmas (Moore and Schilling, 1973; Mathez, 1976; Czamanske and Moore, 1977) as well as high-temperature/pressure experiments (Haughton et al., 1974; Mysen and Popp, 1980; Wendlandt, 1982) show that many mafic magmas are saturated in sulfur and form immiscible sulfide globules. In some cases, the sulfides, which have great affinity for the PGE (measured sulfide/magma partitioning coefficients for $\mathrm{Pd}$ and $\mathrm{Ir}$ are $2.3 \times 10^{4}$ and $2.8 \times 10^{4}$, respectively; C. Peach and E. Mathez, pers. comm., 1989) equilibrate with large volumes of magma and effectively scavenge it of PGE (Campbell and Barnes, 1984). Some magmatic PGE deposits have been attributed to concentration of the sulfides (Naldrett, 1981).

Trace element modeling calculations indicate that $\mathrm{Cu}$ behaved as an incompatible element in Site 715 magmas (Table 2), circumstantially implying that the PGE were not removed by sulfides. However, sulfide/magma partitioning coefficients for the PGE are much larger than the value for $\mathrm{Cu}(\sim 250$; Rajamani and Naldrett, 1978), such that minute amounts of sulfide removal (assuming equilibration with large amounts of magma) could drastically reduce PGE concentrations but have little effect on $\mathrm{Cu}$ concentrations (Campbell and Barnes, 1984). At the present time, it appears that the sulfide model cannot be quantitatively tested because the amount of sulfide removed (if any) cannot be ascertained. It remains to be demonstrated that tiny sulfide globules (like small alloy grains), despite their high density, would gravitationally settle from a magma. The similarity between $\mathrm{Ir}$ and $\mathrm{Pd}$ partitioning coefficients indicates that both metals should be equally removed by sulfide fractionation processes. Table 2 shows that, for the lower lavas at Site 715, Pd increases $6 \%$ whereas Ir shows an $86 \%$ decrease, thus arguing against sulfide removal as the only process controlling noble metal concentrations.

In trying to explain the low concentrations of PGE in many MORB, Brugmann et al. (1987) proposed sulfide removal as an answer. They explained the high $\mathrm{Pd} / \mathrm{Ir}$ ratios of MORB basalts by concomitant removal of chromite or olivine. A combination of processes may be responsible for decreases in noble metal concentrations in Leg 115 basalts. The effects of silicate mineral removal are explored below.

\section{Fractionation of Silicate Minerals}

Commonly, silicate precipitation has been considered unimportant in controlling PGE concentrations in mafic magmas (Brugmann et al., 1987). However, various studies have shown that olivine-rich rocks contain high Ir values (Gijbels et al., 1976; Oshin and Crocket, 1982; Crocket and MacRae, 1986), and Ross and Keays (1979) reported high Ir contents (5.7 ppb) for cumulus olivine from an Australian komatiite flow. These data appear at odds with the low Ir contents of olivine from spinel and garnet lherzolites (0.07-0.5 ppb; Mitchell and Keays, 1981), but the lherzolite olivine probably equilibrated with sulfides that would scavenge most of the Ir (Brugmann et al., 1987). Ionic size and charge data (Shannon, 1976) indicate that $\mathrm{Ir}$, Os, and $\mathrm{Ru}$ could substitute for $\mathrm{Fe}^{2+}$ and $\mathrm{Mg}^{2+}$ in olivine (Brugmann et al., 1987). Finally, Brugmann et al. (1987) rather convincingly show that Ir, Os, and Ru variations in two komatiite suites are probably related to olivine fractionation.

If silicate precipitation lowered noble metal abundances in Leg 115 basalts, then some mineral other than olivine removed $\mathrm{Au}, \mathrm{Pt}, \mathrm{Pd}$, and $\mathrm{Rh}$, or olivine-partitioning coefficients for these elements must be much higher in basaltic magmas than in komatiitic lavas. The PGE concentrations in lherzolite mineral separates (Mitchell and Keays, 1981) are interesting in this regard because noble metal abundances in clinopyroxene are con- siderably greater (4-5 times for Pd) than in olivine. Lee and Tredoux (1986) report that lower zone and lower critical zone pyroxenites from the eastern Bushveld complex contain more Ir than dunites, indicating that pyroxene might remove the PGE. Given the siderophile character of the noble metals, one might predict higher abundances in ferromagnesian minerals than in the feldspars. The silicate fractionation model is presently not testable because partitioning coefficient data are unavailable. Nevertheless, we think that olivine and pyroxene removal of the PGE is a possibility.

In summary, the most important argument against sulfide removal as the only process controlling the PGE in Leg 115 basalts is that Ir was preferentially removed relative to $\mathrm{Pd}$ in some Site 715 lavas. Control of PGE concentrations by chromite or PGE alloy removal is not supported by concentration decreases for all of the noble metals in most of the Leg 115 basalts (chromite and alloys mainly remove $\mathrm{Ir}$, Os, and $\mathrm{Ru}$ ). Trace element information does not support appreciable chromite removal. The available data do not unequivocally eliminate any of the above processes or the possibility that abundances were simply controlled by the precipitation of silicate phases.

\section{MANTLE PROCESSES}

Given that magma evolution unquestionably affects noble metal concentrations in magma series, it is necessary to determine whether major differences in average noble metal ratios (e.g., Pd/Ir) and concentrations between rock groups (Table 3) represent mantle processes or magma evolution processes or both. Hamlyn et al. (1985) and Brugmann et al. (1987) noted that MORB are depleted in Pd by a factor of 100 and Ir by 1000 compared with komatiites. They attributed the low concentrations to sulfide fractionation. However, when suites of rocks (showing a range of primitive to evolved rock types) from distinct localities were compared, major differences in PGE concentrations were apparent that could not easily be related to sulfide fractionation. Chou et al. (1983) showed that Pd decreases with fractionation from 2 to $0.1 \mathrm{ppb}$ in Leg 37 basalts. In contrast, Site 707 basalts, which resemble MORB in many respects (e.g., $\mathrm{La} / \mathrm{Sm}$ ratios), average $19 \mathrm{ppb}$ in the most evolved rocks. Furthermore, Indian Ocean MORB samples reported by Hamlyn et al. (1985) average $5.7 \mathrm{ppb}$.

Average noble metal abundances decreased with evolution in all Leg 115 basalt suites (except noncomagmatic Site 707 rocks), but absolute abundances at any given degree of evolution (indicated by $\mathrm{Mg}^{\prime}$ values) varied considerably between suites (Fig. 4). Our data also show that the more similar the basalts are to MORB, the higher the noble metal abundances are. In all probability, sulfide removal does in some cases decrease noble metal concentrations, but the major differences in abundances between variably alkaline rocks from similar localities (e.g., Indian Ocean) and between similar rocks from different localities (e.g., Indian vs. Atlantic ocean) more likely reflect source-region processes or variations in concentration.

The effects of magma evolution on $\mathrm{Pd} / \mathrm{Ir}$ ratios have already been discussed. The high $\mathrm{Pd} / \mathrm{Ir}$ ratios of MORB $(\sim 100)$ compared with the primitive komatiites $(\sim 4.5)$ have often been attributed to the removal of olivine, chromite (Hertogen et al., 1980; Crocket, 1981; Brugmann et al., 1987), or Ir-based alloys (Barnes et al., 1985) in the former. Our data show that Pd/Ir ratios are affected by magma evolution, but the data also indicate a greater tendency for the ratios to decrease with fractionation (cf. $\mathrm{Pd} / \mathrm{Ir}$ in primitive vs. evolved rocks at Sites 706, 707, and 713, as shown in Table 2). Data for Leg 37 basalts (Atlantic Ocean) presented by Chou et al. (1983) showed that MORB evolution has little effect on $\mathrm{Pd} / \mathrm{Ir}$ ratios. In summary, the above analysis implies that fractionation of MORB decreases, or has 
little effect on, $\mathrm{Pd} / \mathrm{Ir}$ ratios. For this reason, fractionation would only serve to decrease differences between the $\mathrm{Pd} / \mathrm{Ir}$ ratios of MORB and primitive komatiites.

Following the above reasoning, one might conclude that the low $\mathrm{Pd} / \mathrm{Ir}$ ratios of other types of basalts (e.g., oceanic-island alkali basalts; see Table 3) compared with MORB do not reflect magma evolution processes. A comparison of primitive groups of Leg 115 basalts (Table 2) shows that $\mathrm{Pd} / \mathrm{Ir}$ ratios increase from 25 in Site 706 basalts (among the most alkaline of primitive Leg 115 basalts with $\mathrm{La} / \mathrm{Sm} \sim 2.0$ ) to 707 in Site 715 basalts (the least alkaline, with $\mathrm{La} / \mathrm{Sm} \sim 0.54$ ). This relationship between alkalinity and $\mathrm{Pd} / \mathrm{Ir}$ ratios is mirrored in Table 3 , with alkali basalts showing the lowest $\mathrm{Pd} / \mathrm{Ir}$ ratios $(\sim 5)$ and MORB and Leg 115 data (keep in mind geochemical similarities between Leg 115 basalts and MORB) displaying the highest ratios $(\sim 100-74)$. It seems unlikely that the relationship between $\mathrm{Pd} /$ Ir ratios and alkalinity can easily be ascribed to magma evolution processes. It most likely reflects mantle processes.

\section{Mantle Processes and Magma Pd/Ir Ratios}

Studies of purported upper-mantle materials provide an explanation for the wide variation in $\mathrm{Pd} / \mathrm{Ir}$ ratios of mafic rocks. The chondrite-normalized PGE patterns of fairly undepleted spinel lherzolite xenoliths from alkaline rocks are flat, with the PGE predominantly held in intergranular sulfide phases apparently trapped during or after melting (Jagoutz et al., 1979; Morgan et al., 1981; Mitchell and Keays, 1981). Harzburgites and dunites representing post-melt extraction residues show normalized patterns enriched in $\mathrm{Os}, \mathrm{Ir}$, and $\mathrm{Ru}$ relative to $\mathrm{Pt}, \mathrm{Pd}$, and $\mathrm{Rh}$ with the PGE concentrated in alloy phases (Page and Talkington, 1984; Barnes et al., 1985; Rudashevskiy, 1987).

The details of PGE mineralogy are complicated (there are many minerals) in both the lherzolites and residue rocks; thus, the simple sulfide-alloy division of assemblages is only general. Bird and Bassett (1980) proposed that textural and compositional relationships of some Ir-Os alloys are consistent with high formation temperatures during accretion of the earth. However, the alloys apparently show increased abundances as the percentages of sulfide decrease (Rudashevshiy, 1987), which supports the hypothesis of F. A. Frey (1983, pers. comm. in Barnes et al., 1985) that they formed through incongruent melting of the sulfides.

The high Ir contents of komatiites compared with basalts (Table 3), and arguments that komatiites represent high percentage melts (BVSP, 1981, pp. 26-27), indicate that the low Pd/Ir ratios of komatiites (Brugmann et al., 1987) result from melting both alloys and sulfides (Barnes et al., 1985). Low $\mathrm{Pd} / \mathrm{Ir}$ ratios in alkali basalts imply melting of a source with residual sulfides and alloys. Because sulfides are expected to dissolve before alloys, the high $\mathrm{Pd} / \mathrm{Ir}$ ratios of basalts, which represent greater percentages of melting than alkali basalts, could be produced by fusion of the sulfides, with alloys remaining in the residue. The model implies that the increase in $\mathrm{Pd} / \mathrm{Ir}$ ratios and Pd concentrations with decreasing alkalinity in Leg 115 basalts could reflect the highly compatible behavior of the noble metals during melting, with the progressive release of $\mathrm{Pd}$ from the sulfides with increased melting.

\section{Noble Metal Concentrations in the Mantle}

The mantle may be extremely heterogeneous with regard to its noble metal content. Although there are few data for noble metal abundances in Atlantic OIB, LILE-enriched basalts from the FAMOUS area, like Atlantic MORB, show low noble metal abundances (Hertogen et al., 1980). Both tholeiitic basalts and LILE-enriched alkali basalts from the East Pacific Rise have low Ir concentrations (typically $<0.05 \mathrm{ppb}$ ) (Gottfried and Greenland, 1972). Relative to typical MORB, Leg 115 hotspot basalts with MORB affinities and Indian MORB display high noble metal concentrations (Table 3). Crocket and Skippen (1966) found that Deccan flood basalts (northern end of Réunion hotspot trace) have higher Pd concentrations than flood basalts from the Parana Basin, Columbia-Snake River Plateau, or Karroo provinces. These observations suggest that mantle noble metal abundances vary dramatically from place to place. For example, mantle noble metal abundances for the Indian Ocean area may be anomalously high compared with the Atlantic Ocean area.

Gottfried and Greenland (1972) indicated that the apparently higher noble metal abundances of OIB compared with MORB reflect differences in source mineralogy, depth and degree of partial melting, and/or inherent variations in mantle concentrations. They also pointed out that noble metal concentrations appear to correlate with ${ }^{87} \mathrm{Sr} /{ }^{86} \mathrm{Sr}$ ratios in basalts and implied that the low Pd concentrations of MORB may be a result of previous melt extraction. We argued with our Leg 115 data that noble metal concentrations, particularly $\mathrm{Au}$ and $\mathrm{Pd}$, rise as melting percentages increase because they are compatible in mantle minerals. The compatible melting behavior implies that concentrations in the residue will always be higher than in unmelted material and subsequent magmas generated from the same source will have higher concentrations than the initial magma. If so, the low Pd concentrations of many MORBs are difficult to explain by previous melt extraction because Pd should be enriched in subsequent magmas.

Some OIB contain too much $\mathrm{Rb}$ for their observed ${ }^{87} \mathrm{Sr} /{ }^{86} \mathrm{Sr}$ ratios, which implies that their sources were metasomatically enriched in LILE a short time prior to melt extraction (Sun and Hanson, 1975). Noble metal abundances decrease in Leg 115 basalts derived from sources most likely to show the effects of mantle metasomatism (i.e., those with the highest abundances of LILE). Similarly, Hamlyn et al. (1985) found no covariance between light rare-earth-element and PGE concentrations in low-titanium, magnesium-rich lavas from various localities. In their study of mantle xenoliths, Mitchell and Keays (1981) concluded that mantle metasomatism is probably not responsible for the intergranular sulfides that contain the bulk of the PGE because concentrations in the transporting fluids would have to be prohibitively high and the fluids would have to transport the metals in chondritic proportions. Jagoutz et al. (1979) reported that noble metal concentrations in mantle nodules show no relationship to elements commonly influenced by metasomatism. Apparently, processes other than previous melt extraction or mantle metasomatism are responsible for differences in noble metal concentrations in basalts from different areas.

\section{SUMMARY AND CONCLUSIONS}

For any one site, evolved Leg 115 hotspot basalts generally show lower noble metal concentrations than more primitive basalts. The concentration decreases may be related to the removal of Ir-Os-based alloys, chromite, sulfides, or olivine and clinopyroxene in some combination. A lack of partitioning coefficients for the noble metals prevents the quantitative testing of the various possibilities, but the simplest explanation is that olivine and clinopyroxene fractionation is the major cause of removal of the noble metals.

$\mathrm{The} \mathrm{Pd} / \mathrm{Ir}$ ratios decrease with magma alkalinity in Leg 115 basalts and basalts worldwide. This observation is consistent with retention of the noble metals in mantle sulfide and Ir-Osbased alloy phases. Although the alloys retain high-meltingpoint metals up to high percentages of melting, the sulfides dissolve with increasing percentages of melting and thereby release the low-melting-point noble metals (e.g., Pd), which causes Pd/ Ir ratios to increase.

Indian OIB and MORB are characterized by anomalously high noble metal concentrations, whereas Atlantic MORB and East Pacific Rise MORB show extremely low noble metal abun- 
dances. These observations indicate a provinciality to noble metal abundances that cannot easily be related to percentages of melting or previous melt extraction. The concentration differences may reflect fundamental primary differences in mantle noble metal abundances related to core formation or cosmochemical processes.

\section{ACKNOWLEDGMENTS}

We wish to acknowledge the support and assistance of all persons in the Ocean Drilling Program who made acquisition of the samples possible. H. Longerich, S. Jackson, and W. Gosse carried out the noble metal analyses; B. Webb prepared the tables; and K. Steinhauer created the diagrams. E. Mathez, A. Naldrett, and C. Peach provided useful reviews. This research was supported by a Collaborative Special Projects grant to the authors from NSERC.

\section{REFERENCES}

Agiorgitis, G., and Wolf, R., 1978. Aspects of osmium, ruthenium, and iridium contents in some Greek chromites. Chem. Geol., 23:267272.

1984. Variations of the Os/Ir ratio in terrestrial rocks and minerals. Chem. Geol. 42:277-286.

Backman, J., Duncan, R. A., et al., 1988. Proc., ODP, Init. Repts., 115: College Station, TX (Ocean Drilling Program).

Barnes, S.-J., and Naldrett, A. J., 1985. Geochemistry of the J-M (Howland) reef of the Stillwater complex, Minneapolis adit area. I. Sulfide chemistry and sulfide-olivine equilibrium. Econ. Geol., 80: 627-645.

Barnes, S.-J., Naldrett, A. J., and Gorton, M. P., 1985. The origin of the fractionation of platinum group elements in terrestrial magmas. Chem. Geol., 53:303-323.

Basaltic Volcanism Study Project, 1981. Basaltic Volcanism on the Terrestrial Planets: New York (Pergamon Press).

Bird, J. M., and Bassett, W. A., 1980. Evidence of deep mantle history in terrestrial osmium-iridium-ruthenium alloys. J. Geophys. Res., 85:5461-5470.

Boudreau, A. E., Mathez, E. A., and McCallum, I. S., 1986. Halogen geochemistry of the Stillwater and Bushveld complexes: evidence for transport of the platinum-group elements by $\mathrm{Cl}$-rich fluids. J. Petrol., 27:627-645.

Brugmann, G. E., Arndt, N. T., Hofmann, A. W., and Tobschall, H. J., 1987. Noble metal abundances in komatiite suites from Alexo, Ontario, and Gorgona Island, Columbia. Geochim. Cosmochim. Acta, $51: 2159-2169$.

Bryan, W. B., Finger, L. W., and Chayes, F., 1969. Estimating proportions in petrographic mixing equations by least-squares approximation. Science, 163:926-927.

Bryan, W. B., Frey, F. A., and Thompson, G., 1977. Oldest Atlantic sea-floor: Mesozoic basalts from western North Atlantic margin and eastern North America. Contrib. Mineral. Petrol., 64:223-242.

Campbell, I. H., and Barnes, S. J., 1984. A model for the geochemistry of the platinum-group elements in magmatic sulfide deposits. Can. Mineral., 22:151-160.

Chou, C.-L., 1978. Fractionation of siderophile elements in the earth's upper mantle. Geochim. Cosmochim Acta, Suppl., 10:219-230.

Chou, C.-L., Shaw, D. M., and Crocket, J. H., 1983. Siderophile trace elements in the earth's oceanic crust and upper mantle. J. Geophys. Res., Suppl. A, 88:507-518.

Crocket, J. H., 1981. Geochemistry of the platinum group elements. In Cabri, L.J. (Ed.), Platinum Group Elements: Mineralogy, Geology, Recovery. CIM Spec. Vol., 23:47-64.

Crocket, J. H., and Chyi, L. L., 1972. Abundances of Pd, Ir, Os and Au in an alpine ultramafic pluton. Int. Geol. Congr., Rep. Sess., 24th, 1972, Section 10:202-209.

Crocket, J. H., Macdougall, J. D., and Harriss, R. C., 1973. Gold, palladium and iridium in marine sediments. Geochim. Cosmochim. Acta, 37:2547-2556.

Crocket, J. H., and MacRae, W. E., 1986. Platinum-group element distribution in komatiitic and tholeiitic volcanic rocks from Munro Township, Ontario. Econ. Geol., 81:1242-1251.
Crocket, J. H., and Skippen, G. B., 1966. Radioactivation determination of palladium in basaltic and ultrabasic rocks. Geochim. Cosmochim. Acta, 30:129-141.

Crocket, J. H., and Teruta, Y., 1977. Palladium, iridium, and gold contents of mafic and ultramafic rocks drilled from the Mid-Atlantic Ridge, Leg 37, Deep Sea Drilling Project. Can. J. Earth Sci., 14: 777-784.

Czamanske, G. K., and Moore, J. G., 1977. Composition and phase chemistry of sulfide globules in basalt from the Mid-Atlantic Ridge rift valley near $37^{\circ} \mathrm{N}$ lat. Geol. Soc. Am. Bull., 88:587-599.

Duncan, R. A., Backman, J., and the Shipboard Scientific Party, 1989. Réunion hotspot activity through Tertiary time: initial results from the Ocean Drilling Program, Leg 115. Volcanol. Geotherm. Res., 36:193-198.

Evans, J. L., 1978. An alkalic volcanic suite of the Labrador Trough, Labrador [M.Sc. thesis]. Memorial Univ., St. John's, Newfoundland, Canada.

Fisk, M. R., Baxter, A. N., Duncan, R. A., Greenough, J. D., Hargraves, R. B., and Tatsumi, Y., 1989. Deccan-Réunion hotspot magma chemistry over the past 65 m.y.: results from Leg 115 of the Ocean Drilling Program. Geology, 17:934-937.

Frey, F. A., Bryan, W. B., and Thompson, G., 1974. Atlantic Ocean floor: geochemistry and petrology of basalts from Legs 2 and 3 of the Deep Sea Drilling Project. J. Geophys. Res., 79:5507-5527.

Gast, P. W., 1968. Trace-element fractionation and the origin of tholeiitic and alkaline magma types. Geochim. Cosmochim. Acta, 32: $10 \AA 7-1086$.

Gijbels, R., Henderson, P., and Zels, J., 1976. Geochemistry of some trace elements in mineral separates from Rhum, Inner Hebrides, with special emphasis on iridium. Econ. Geol., 71:1364-1370.

Gottfried, D., and Greenland, L. P., 1972. Variation of iridium and gold in oceanic and continental basalts. Int. Geol. Congr., Rep. Sess., 24th, 1972, Section 10:135-144.

Gottfried, D., Rowe, J. J., and Tilling, R. I., 1972. Distribution of gold in igneous rocks. Geol. Surv., Prof. Pap. (U.S.), No. 727.

Hamlyn, P. R., Keays, R. R., Cameron, W. E., Crawford, A. J., and Waldron, H. M., 1985. Precious metals in magnesian low-Ti lavas: implications for metallogenesis and sulfur saturation in primary magmas. Geochim. Cosmochim. Acta, 49:1797-1811.

Haughton, R., Roeder, P. L., and Skinner, B. J., 1974. Solubility of sulfur in mafic magmas. Econ. Geol., 69:451-467.

Hertogen, J., Janssens, M.-J., and Palme, H., 1980. Trace elements in ocean ridge basalt glasses: implications for fractionations during mantle evolution and petrogenesis. Geochim. Cosmochim. Acta., 44:2125-2143.

Hiemstra, S. A., 1979. The role of collectors in the formation of platinum deposits in the Bushveld Complex. Can. Mineral., 17:469-482.

Jagoutz, E., Palme, H., Baddenhausen, H., Blum, K., Cendales, M., Gerlind, D., Spettel, B., Lorenz, V., and Wanke, H. 1979. The abundances of major, minor, and trace elements in the earth's mantle as derived from primitive ultramafic nodules. Geochim. Cosmochim. Acta, Suppl., 11:2031-2050.

Keays, R. R., 1982. Palladium and iridium in komatiites and associated rocks: application to petrogenetic problems. In Arndt, N. T., and Nisbett, E. G. (Eds.), Komatiites: London (Allen \& Unwin), 435457.

Keays, R. R., and Campbell, I. H., 1981. Precious metals in the Jimberlana Intrusion, Western Australia: implications for genesis of platiniferous ores in layered intrusions. Econ. Geol., 76:1118-1141.

Keays, R. R., and Crocket, J. H., 1970. A study of precious metals in the Sudbury nickel irruptive ores. Econ. Geol., 65:438-450.

Langmuir, C. H., Bender, J. F., Bence, A. E., and Hanson, G. N., 1977. Petrogenesis of basalts from the FAMOUS area: Mid-Atlantic Ridge. Earth Planet. Sci. Lett., 36:133-156.

Lee, C. A., and Tredoux, M., 1986. Platinum-group element abundances in the lower and lower critical zones of the eastern Bushveld Complex. Econ. Geol., 81:1087-1095.

Macdonald, A. J., 1987. Ore Deposits \#12. The platinum group element deposits: classification and genesis. Geosci. Can., 14:155-166.

Mathez, E. A., 1976. Sulfur solubility and magmatic sulfides in submarine basalt glass. J. Geophys. Res., 81:4269-4276.

Melson, W. G., Vallier, T. L., Wright, T. L., Byerly, G., and Nelen, J., 1976. Chemical diversity of abyssal volcanic glass erupted along $\mathrm{Pa}-$ 
cific, Atlantic and Indian Ocean seafloor spreading centers. In Sutton, G. H., Manghani, M. H., and Moberly, R. (Eds.), The Geophysics of the Pacific Ocean Basin and Its Margin: Washington (American Geophysical Union). AGU Monogr. Ser., 19:351-367.

Mitchell, R. H., and Keays, R. R., 1981. Abundance and distribution of gold, palladium and iridium in some spinel and garnet lherzolites: implications for the nature and origin of precious metal-rich intergranular components in the upper mantle. Geochim. Cosmochim. Acta., 45:2425-2442.

Moore, J. G., and Schilling, J.-G., 1973. Vesicles, water, and sulfur in Reykjanes Ridge basalts. Contrib. Mineral. Petrol., 41:105-118.

Morgan, J. W., Wandless, G. A., Petrie, R. K., and Irving, A. J., 1981. Composition of the earth's upper mantle. 1. Siderophile trace elements in ultramafic nodules. Tectonophysics, 75:47-67.

Mysen, B. O., and Popp, R. K., 1980. Solubility of sulfur in $\mathrm{CaMgSi}_{2} \mathrm{O}_{6}$ and $\mathrm{NaAlSi}_{3} \mathrm{O}_{8}$ melts at high pressure and temperature with controlled $\mathrm{f}_{2}$ and $\mathrm{f}_{\mathrm{S}_{2}}$. Am. J. Sci., 280:78-92.

Naldrett, A. J., 1981. Platinum-group element deposits. In Cabri, L. J. (Ed.), Platinum Group Elements: Mineralogy, Geology, Recovery. CIM Spec. Vol., 23:197-231.

Naldrett, A. J., Hoffman, E. L., Green, A. H., Chou, C.-L., Naldrett, S. R., and Alcock, R. A., 1979. The composition of Ni-sulphide ores, with particular reference to their content of PGE and Au. Can. Mineral., 17:403-415.

Nathan, H. D., and Van Kirk, C. K., 1978. A model of magmatic crystallization. J. Petrol., 19:66-94.

Oshin, I. O., and Crocket, J. H., 1982. Noble metals in Thetford Mines ophiolites, Quebec, Canada. Part I: Distribution of gold, iridium, platinum, and palladium in the ultramafic and gabbroic rocks. Econ. Geol., 77:1556-1570.

Page, N. J., and Talkington, R. W., 1984. Palladium, platinum, rhodium, ruthenium, and iridium in peridotites and chromites from ophiolite complexes in Newfoundland. Can. Mineral., 22:137-149.

Pearce, J. A., and Cann, J. R., 1973. Tectonic setting of basic volcanic rocks determined using trace element analyses. Earth Planet. Sci. Lett., 19:290-300.

Philpotts, J. A., and Schnetzler, C. C., 1970. Phenocryst-matrix partition coefficients for $\mathrm{K}, \mathrm{Rb}, \mathrm{Sr}$, and $\mathrm{Ba}$ with applications to anorthosite and basalt genesis. Geochim. Cosmochim. Acta, 34:307-322.
Prichard, H. M., Potts, P. J., and Neary, C. R., 1981. Platinum group element minerals in the Unst chromite, Shetland Isles. Trans. Inst. Min. Metall., Sect. B, 90:186-188.

Rajamani, V., and Naldrett A. J., 1978. Partitioning of Fe, Co, Ni, and $\mathrm{Cu}$ between sulfide liquid and basaltic melts and the composition of Ni-Cu sulfide deposits. Econ. Geol., 73:82-93.

Ross, J. R., and Keays, R. R., 1979. Precious metals in volcanic-type nickel sulfide deposits in western Australia. I. Relationship with the composition of the ores and their host rocks. Can. Mineral., 17: 417-435.

Rudashevskiy, N. S., 1987. Origin of the various types of platinoid mineralization in ultramafic rocks. Int. Geol. Rev., 29:465-480. [Transl. from Zap. Vseross. Mineral., 1987, 116(2):222-238.]

Schiffries, C. M., and Skinner, B. J., 1987. The Bushveld hydrothermal system: field and petrologic evidence. Am. J. Sci., 287:566-595.

Schilling, J.-G., 1971. Sea-floor evolution: rare-earth evidence. Philos. Trans. R. Soc. London., Ser. A, 268:663-706.

Shannon, R. D., 1976. Revised effective ionic radii and systematic studies of interatomic distances in halides and chalcogenides. Acta Crystallogr., 32:751-767.

Stockman, H. W., and Hlava, P. F., 1984. Platinum-group minerals in Alpine chromitites from southwestern Oregon. Econ. Geol., 79:491508.

Sun, S. S., and Hanson, G. N., 1975. Evolution of the mantle: geochemical evidence from alkali basalt. Geology, 3:297-300.

Talkington, W., Watkinson, D. H., Whittaker, P. J., and Jones, P. C., 1983. Platinum-group mineral inclusions in chromite from the Bird River Sill, Manitoba. Miner. Deposita, 18:245-255.

Wendlandt, R. F., 1982. Sulfide saturation of basalt and andesite melts at high pressures and temperatures. Am. Mineral., 67:877-885.

Wood, S. A., 1987. Thermodynamic calculations of the volatility of the platinum group elements (PGE): the PGE content of fluids at magmatic temperatures. Geochim. Cosmochim. Acta, 51:3041-3050.

Date of initial receipt: 17 July 1988

Date of acceptance: 11 September 1989

Ms 115B-128 